\title{
On 'Reconsidering Regional Political Ecologies' 13 years on
}

\author{
Peter Walker ${ }^{1}$ \\ University of Oregon, USA
}

\begin{abstract}
Is the region "dead"? I argue that for all its ambiguity, complexity, negotiability, fluidity, and sociallyconstructedness, the region is not dead and neither should it be. If for no other reason, this is true because so many non-geographers continue to firmly believe in and practice the heresy of the region. Perhaps equally importantly, can it really be argued that no important geographic phenomena occur at the meso-scale? There are certainly many quite real geographic phenomena that exist at scales that cannot be described as either global or local_-and for which we have no better word than "regional." The region is a cognitive expression of geographic coherence; and all things put together can and do fall apart through continuous processes of social, environmental, political and economic change. In the end, the declaration of the "death" of the region is not really a choice that geographers will make. The world will go on thinking and acting in regional ways. The question is not whether the region is dead-it is not. And the question is not even whether the region is problematic - it is. The question instead is whether geographers will take the lead in understanding and educating about the region in all its problematic complexity, a task, I argue, we are well suited to do.
\end{abstract}

Keywords: region, political ecology, geography

\section{Résumé}

La région est-elle "morte"? Je soutiens que, malgré son ambiguïté, sa complexité, sa négociabilité, sa fluidité et le fait qu'elle soit une construction sociale, la région n'est pas morte et ne devrait pas l'être. Cette affirmation est vraie ne serait-ce que parce que de nombreux non-géographes continue de croire fermement au concept hérétique de région et de l'utiliser dans leur travaux. Peut-être de manière également importante, peuton vraiment prétendre qu'aucun phénomène géographique important ne se déroule à méso-échelle? Il y a certainement de nombreux phénomènes géographiques réels qui ne peuvent être décrit comme globaux ou locaux, et pour lesquels nous n'avons pas de mot plus approprié que le mot « régional ». La région est une expression cognitive de cohérence géographique; et toute les choses que l'on rassemble peuvent, et finissent par, se dissocier lors de processus continus de changement social, environnemental, politique et économique. Au final, la proclamation de la «mort » de la région n'est pas vraiment un choix que les géographes sont en pouvoir de faire. Le monde continuera de penser et d'agir de manières régionales. La question n'est pas de savoir si la région est morte; elle ne l'est pas. Et la question n'est pas même de savoir si la région est problématique; elle l'est. La question est plutôt de savoir si les géographes prendront en main la compréhension et l'éducation relatives à la région dans toute sa complexité problématique, une tache pour laquelle, je le soutiens, nous sommes parfaitement équipés.

Mots-clés: région, écologie politique, géographie

\section{Resumen}

¿Está "muerta" la región? En este texto argumento que a pesar de su ambigüedad, complejidad, negociabilidad, fluidez y conceptualización social, la región no está muerta ni debería estarlo. Esto es debido, aunque no haya alguna otra razón, a que muchos no-geógrafos continúan a creer firmemente en, y a practicar, la herejía de la región. Talvez de igual importancia habría que preguntar si ¿puede realmente argumentarse que ningún fenómeno geográfico importante puede ocurrir a escala intermedia? Ciertamente hay muchos verdaderos fenómenos geográficos que existen a escalas que no pueden ser descritas ni como global ni localy para los cuales no tenemos mejor palabra que la de "regional." La región es una expresión cognitiva de coherencia geográfica; y toda entidad construida puede desarmarse a través de continuos procesos de cambio

\footnotetext{
${ }^{1}$ Dr. Peter Walker, Professor, Department of Geography, University of Oregon, Eugene OR, USA. Email: pwalker "at" uoregon.edu. This is the second article in Colleen Hiner and Innisfree McKinnon (eds.) 2016. "(Re)considering regional political ecology?", Special Section of the Journal of Political Ecology 23: 115-203.
} 
social, ambiental, político y económico. Al final, la declaración de la "muerte" de la región no es realmente una decisión que geógrafos tomarán. El mundo seguirá pensando y actuando en formas regionales. La pregunta no es si la región está muerta—no lo está. Y la pregunta ni siquiera es si la región es problemáticalo es. En cambio, la pregunta es si los geógrafos tomaremos la iniciativa de entender y educar sobre la región con toda su problemática complejidad, una tarea para la cual, propongo, estamos bien capacitados para realizar.

Palabras clave: región, ecología política, geografía

I was asked to write this commentary as a follow-up to a panel presentation that I gave at the 2014 annual conference of the American Association of Geographers (AAG), which, in turn, I gave as a follow-up to an article that I published in 2003 on the question of the region in political ecology. I was reluctant to give the presentation, and I am reluctant to write this commentary because I am no expert on the history of the idea of the region. I offer my apologies for the inevitable failures to engage and acknowledge certain ideas and contributions of those who actually are experts on this topic. To be (perhaps overly) blunt, the 2003 article that led me into this predicament was written in a state of pre-tenure eagerness to produce publishable and citable articles. A lesson that can be drawn here is that, for good or ill, one still "owns" such publications many years later, when one has moved on to other topics.

In any event, at the 2014 AAG panel I began with the observation that I find it surprising that we are still arguing about the region. I noted a session at the meeting with the title, Death (again) of the 'Region'? (the title might have been rhetorical). With trepidation in deference to those who have studied the region in more depth, I might speculate that rejecting old school descriptive regional geography has become conflated with the everyday practical use of the region as a reasonably useful concept. Certainly, in ordinary, everyday use, "the region" seems rather alive. We have regional specialty groups for the AAG (Africa, Asia, European, Latin American, Middle East, etc.); we teach courses on World Regions, Geography of Africa, Geography of North Africa and the Middle East and so-on; and our curriculum vitae not uncommonly define our professional identities in terms of our expertise in regions such as The American West or Eastern Europe. How can a concept that we use on a daily basis be so "dead"?

I argue that for all its ambiguity, complexity, negotiability, fluidity, and socially-constructedness (etc.) that has been so aptly demonstrated in geography since the second half of the $20^{\text {th }}$ century, the region is not dead, and neither should it be. If for no other reason, this is true because so many non-geographers continue to firmly believe in and practice the heresy of the region.

Perhaps the premier Africanist scholar of our time, anthropologist James Ferguson, aptly points out that for all its vast diversity and ambiguity, the idea of "Africa", for example, is real because it is such a common part of our cultural vernacular. As an illustration, in September and October 2014, I conducted field research in Gabon, South Africa and Malawi at the exact time when Americans were seized with near-hysteria about the Ebola virus traveling across international borders. When I returned home, I was greeted with halfjoking comments by friends and neighbors, and even my university colleagues, regarding whether I might be an Ebola carrier, since I had just returned from "Africa." The fact that I had traveled to no country in Africa with any known occurrence of Ebola was, apparently, irrelevant. So was the ironic fact that the only time I actually entered a country with Ebola present was when I returned from Africa to the United States. It seemed that 115 years after the publication of Joseph Conrad's Heart of darkness, in the western mind "Africa" remains a coherent entity, regrettably often bound together by irrational fears-but bound together nonetheless. Africa is a "region" of the imagination, yes-but with very real implications (for example, for health care workers who returned home from their heroic work to be greeted by medically baseless quarantine policies). The same argument can obviously be applied to places such as "the Middle East", "East Asia", or "Western Europe" (etc.).

Equally importantly, can it really be argued that no important geographic phenomena occur at the meso-scale? There are certainly many quite real geographic phenomena that exist at scales that cannot be described as either global or local—and for which we have no better word that I know of than "regional." But, having learned a few things from the numerous critiques of the "region", clearly there is nothing a priori or 
static about the region. The region is a cognitive expression of geographic coherence; and all things put together can and do fall apart through continuous processes of social, environmental, political and economic change. But some forms of geographic coherence at the meso-scale, even while in constant flux and in various states of ambiguity and contestability, do persist in meaningful ways.

Francophone and Anglophone Africa, for example, cannot be divided by a single geographic boundary, but as expressions of geographic coherence they are quite real. Just try buying an airplane ticket from an Anglophone African country to a neighboring Francophone African country. Frequently the shortest distance between these two geographic "regions" is actually through an airport hub in Europe. Your international travel agent might have an opinion on whether Francophone and Anglophone Africa are meaningful geographic concepts existing at a scale that cannot be called global, but that clearly reaches beyond the boundaries of a single nation state. Similarly, the people of Ukraine might have an opinion on whether alliance with "the West" has real, tangible implications. And what is the Islamic State if not an extreme and violent but very real expression of a geographic ideal that extends beyond current nation-state boundaries? If these are not expressions of geographic ideas at a regional scale, what other word do we have?

And whether we acknowledge it or not, the region is an entrenched concept in political ecology perhaps as much as any other geographic field. We speak of the political ecology land use conflicts in the American West, the political ecology of deforestation in Amazonia, the political ecology of farmer-herder conflicts in the African Sahel, and so on. As we should. These are inherently problematic geographic frames that should be used with caution, and thoroughly deconstructed when necessary. But where they provide analytical power, they should be used. In any case, the debate is somewhat moot because we do use the region as a scholarly concept; so the real question is how much we acknowledge it and bring the important questions of contestability, fluidity, and so on into explicit examination.

In the end, the declaration of the "death" of the region is not really a choice that we geographers will make. The world will go on thinking and acting in regional ways. To the people of "the West", "Africa" will remain "dark", the "Middle East" will remain chaotic, and "Amazonia" will remain host to environmental imaginaries saturated and dripping with mythic rainforest waters. And good luck with that flight from Dakar to Lagos. The question is not whether the region is dead-it is not. And the question is not even whether the region is problematic - it is. The question is whether geographers will take the lead in understanding and educating about the region in all its problematic complexity. If we do not, others surely will. And they just as surely will not do it as well. 